\title{
ON THE FINDING OF BIOMPHALARIA TENAGOPHILA NATURALLY INFECTED WITH SCHISTOSOMA MANSONI IN THE STATE OF MINAS GERAIS, BRAZIL (")
}

Alan Lane de MELO (1) and Léggenes Horáclo PEREIRA (1)

\section{S U M M A R Y}

Natural infection in Biomphalaria tenagophila with Schistosoma mansoni was observed for the first time in a small area, in Jaboticatubas, in the State of Minas Gerais, Brazil. In view of this finding, the Authors decided to carry out some detailed investigations, since B. glabrata has been known as the vector snail of schistosomiasis in that State. B. tenagophila was found naturally infected throughout the investigation period (15 months). Strains of the snail and of the parasite were isolated four times, and then maintained at the laboratory through B. tenagophila - hamster passages. The possibilities of B. tenagophila to play a role in the epidemiology of the human disease in the State of Minas Gerais, in the future, are discussed.

\section{N T R O D U C T I O N}

Biomphalaria glabrata has been known as the vector of schistosomiasis mansoni in the State of Minas Gerais, Brazil. It is the main species found naturally infected in that area and maintains the high prevalence of the endemy.

Other species of the genus Biomphalaria, as B. straminea, have been reported to occur naturally infected in Brazil. This snail is an important vector of schistosomiasis in northeastern Brazil, whereas B. tenagophila is the vector of this disease in the south of the country (PARAENSE ${ }^{5}$ ).

In the past, B. tenagophila was considered a less susceptible snail and it was named Pla. norbis immunis by LUTZ ${ }^{3}$, owing to its apparent resistance to infection. The area where schistosomiasis is acquired through infected $\mathbf{B}$. tenagophila is expanding its limits, and strains of $\mathbf{S}$. mansoni more adapted to infect this snail could spread the disease to uninfected areas.
It is worth to mention that the role played by $B$. tenagophila as a vector of this disease is increasing in the last decades.

Although this species occurs in several counties of the State of Minas Gerais, as reported by PARAENSE ${ }^{5}$, the natural infection in this mollusc in that State was observed for the first time by MELO et al. ${ }^{4}$, and reported to the VII Brazilian Congress of Parasitology, in 1982. Further field and laboratory investigations were carried out and the results are presented in this paper.

\section{MATERIALS AND METHODS}

The molluscs were collected in a small stream (named "Córrego da Guia"), near Boa Vista Village, Jaboticatubas County, State of Minas Gerais. The snails were also found in irrigation ditches. After collection, snails were packed inside a wood box with pieces of wet filter paper. At the laboratory, they were remov-

(1) Departamento de Parasitologia e Grupo Interdepartamental de Estudos sobre Esquistossomase (GIDE), ICB/UFMG. Endereço para separatas: GIDE - ICB/UFMG, Caixa Postal 2486, 30000 Belo Horizonte, MG, Brasil

(*) This work received financial support from FINEP, CNPq - Brazll, and the World Fealth Organization, Switzeriand. 
MELO, A. L. de \& PEREIRA, L. F. - On the finding of Blomphalaria tenagophlla naturally infected with Schistosoma mansoni in the State of Minas Gerais, Brazill. Rev. Inst. Med. trop. São Paulo 27:99-101, 1985.

ed to plastic containers filled with spring water, for macroscopic observations. The following day the snails were transferred to Petri dishes with water, individually, and then exposed to artificial light for 1 hour to stimulate cercarial emergence (grossly, natural infection amounted to $17.5 \%$ ). Cercariae shed by infected snails were concentrated as recommended by PELLEGRINO \& MACEDO $^{8}$ and injected in hamsters, subcutaneously (PELLEGRINO \& KATZ ${ }^{7}$ ). Some infected snails were killed with water heated at $70^{\circ} \mathrm{C}$ and dissicated under stereomicroscope (PARAENSE \& DESLANDES 6 ).

The remaining molluscs were maintained in aquaria containing well water and received artificial food and fresh lettuce, according to FREITAS ?

Subsequent generations of the mollusc were maintained at the laboratory, as suggested by the same Author. Hamster - B. tenagophila - hamster passages of parasites were carried out according to PELLEGRINO \& $\mathrm{KATZ}^{7}$. Collections for worms from the hepatic portal system, as well as oogram studies were performed as usual.

Susceptibility of B. glabrata to the isolated strain of the parasite was also investigated by the same procedures.

\section{RESULTS AND COMMENTS}

Data of natural infection in B. tenagophila are summarized in Table $I$. See also map in Fig. 1.

T A B L E I

Natural infection in Blomphalaria tenagophila from Jaboticatubas County, State of Minas Gerais, Brazil

\begin{tabular}{|c|c|c|c|c|c|}
\hline \multirow{2}{*}{\multicolumn{2}{|c|}{$\begin{array}{c}\text { Date } \\
\text { (snail } \\
\text { collectlon) }\end{array}$}} & & \multicolumn{3}{|c|}{ Number of snalls } \\
\hline & & \multicolumn{2}{|r|}{ Examined } & \multirow{2}{*}{$\begin{array}{l}\text { Positive for } \\
\text { S. mansoni } \\
8\end{array}$} & \multirow{2}{*}{$\begin{array}{c}\begin{array}{c}\text { Positive for } \\
\text { xiphidiocercaria }\end{array} \\
3\end{array}$} \\
\hline October & 1981 & 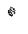 & 23 & & \\
\hline July & 1982 & & 11 & $\mathbf{2}$ & 1 \\
\hline February & 1983 & & 11 & 3 & 3 \\
\hline March & 1983 & & 12 & 5 & 3 \\
\hline TOTAT & & & 57 & 18 & 9 \\
\hline
\end{tabular}

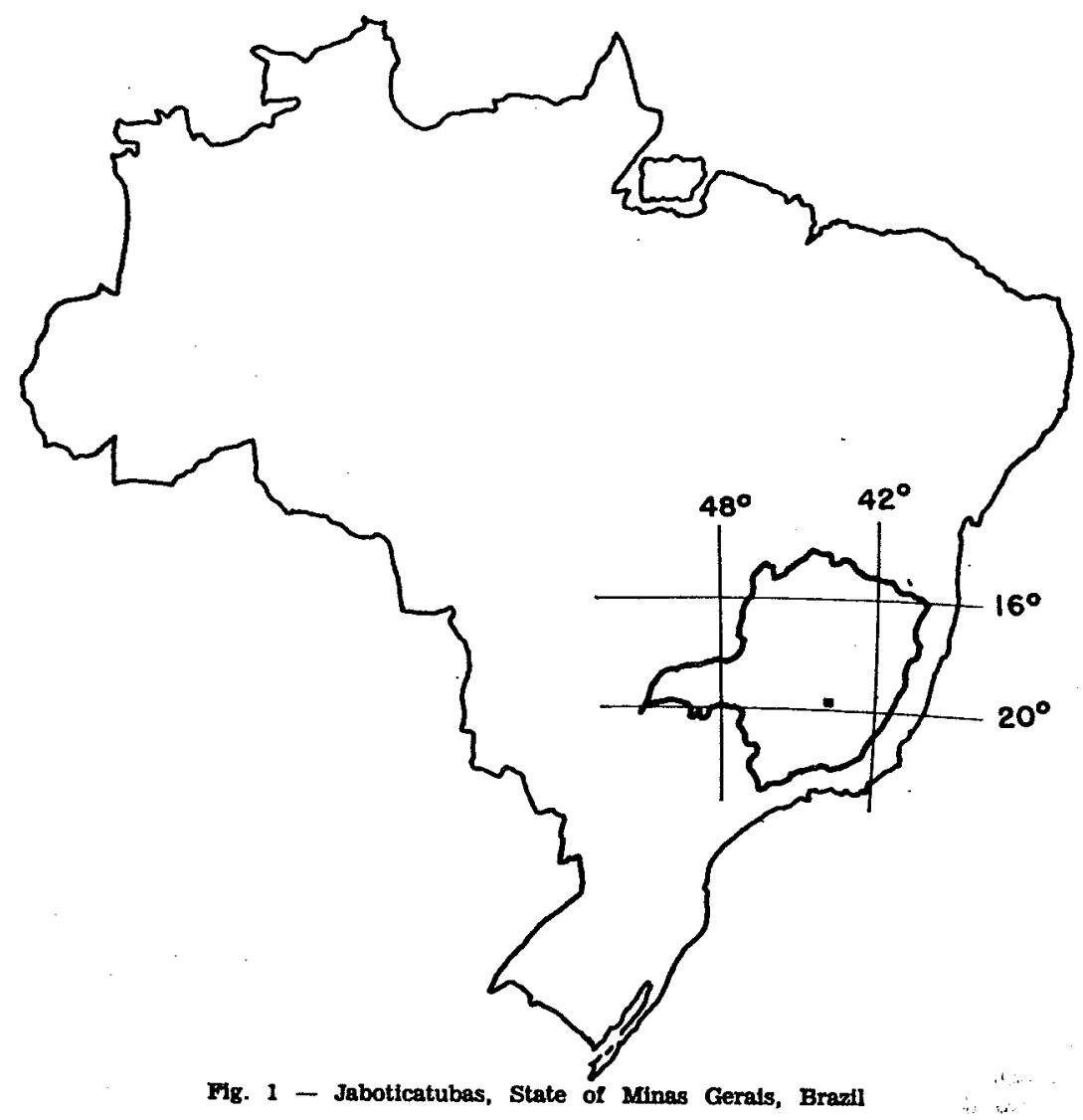


MELO, A. L. de \& PEREIRA, L. H. - On the finding of Blomphalaria tenagophlla naturally infected with Schistosoma mansoni in the State of Minas Gerais, Brazil. Rev. Inst. Med. trop. São Paulo 27:99-101, 1985.

Morphology of cercariae, adult worms, and eggs were found to be typical of S. mansoni. B. tenagophila was easily reared at the laboratory, all four isolations maintained at least to $\mathrm{F}_{2}$ generations.

Hamster - B. tenagophila - hamster passages were successful, the Belo Horizonte strain of B. glabrata being also susceptible to the experimental infection ( $63 \%$ of positivity).

Jaboticatubas has been a well known focus of endemic schistosomiasis through many years. The vector was always referred to as being B. glabrata (RUIZ ${ }^{9}$ ). The finding of $B$. tenagophila with persistent natural infection may be attributed to two different possibilities:

a) A progressive adaptation of the parasite, in an endemic area, to another species of the same genus of the planorbid snail;

b) Contamination of the local B. tenagophila with another strain of the parasite, introduced by a human carrier from a B. tena. gophila transmission area.

Both possibilities must be considered and an epidemiological study involving people living in that area is being carried out.

B. tenagophila has been found in several other counties 'without natural (CARVALHO et al. 1, PEREIRA*) or no autochthon human infection, but foci of this endemic disease may arise in such areas harboring planorbid species.

\section{RESUMO}

Sobre o encontro de Biomphalaria tenagophila naturalmente infectada com Schistosoma mansoni no Estado de Minas Gerais, Brasil

A presença de infecção natural em Biomphalaria tenagophila com o Schistosoma mansoni foi verificada em outubro de 1981, no Município de Jaboticatubas, Minas Gerais. Uma vez que o vetor da esquistossomose mansoni neste Estado é a B. glabrata, este achado deu origem a um trabalho de campo que vem sendo realizado até o presente momento. A B. tenagophila foi encontrada naturalmente infectada durante todo o periodo de observação e as amostras do parasito e do molusco, isoladas quatro vezes, foram mantidas em laboratório através de infecções alternadas hamster - B. tenagophila - hamster. E discutida a possibilidade da B. tenagophila desempenhar futuramente um papel de transmissor secundário da esquistossomose mansoni em Minas Gerais.

\section{REFERENCES}

1. Carvalho, O. S.; MILWARD DE ANDRade, R. \& SOUZA, C. P. - Susceptibilidade de Blomphalaria tenagophlla (d'Orbigny, 1835) de Itajubs, $M G$, \& infecçăo pela cepa LE de Schistosoma mansonl Sambon, 1907, de Belo Horizonte, MG (Brastl). Rev. Saúde Publ. São Paulo 13: 20-25, 1979.

2. FREITAS, J. R. - Ritmo de crescimento da Blom. phalaria glabrata, (Say, 1818). Padronização da téc. nica de crlação. [Tese de Doutorado]. Belo Horizonte, ICB/UFMG, 1973.

3. LUTZ, A. - Planorbis immunis n.n. Nautllus 37: 36, 1923.

4. MELO, A. I.; PEREIRA, L. H. \& CORREA, M. C. R. - Sobre o encontro de Blomphalaria tenagophlla naturalmente infectada com Schistosoma mansoni no $\mathrm{Mu}$. nicipio de Jaboticatubas, MG. Livro de Resumos do VII Congr. Soc. Bras. Parasitol., 63 pp., Porto Alegre, 1982.

5. Paraense, W. L. - Fauna Planorbidica do Brasil. In LACAZ, C. S.; BARUZZI, G. R. \& SIQUEIRA Jr., W. - Introdução à Geogratia Médica do Brasll. Edgara Bliticher (Eds.) Sāo Paulo, Ed. Univ. São Paulo 10: 213-239, 1972

6. PARAENSE, W. L. \& DESLANDES, N. - Observations on the morphology of Australorbis nigricans. Mem. Inst. Oswaldo Cruz 53: 121-134, 1955.

7. PELLEGRINO, J. \& KATZ, N. - Experimental chemotherapy of schistosomiasis mansonl. Adv. Parasitol. 6: 233-290, 1968 .

8. PELLEGRINO, J. \& MACEDO, D. G. - A simplified method for the concentration of cercariae. J. Parasit. 41: $329-330,1955$.

9. RUIZ, J. M. - Contribuição ao estudo das formas larvárias de trematoides brasileiros. 3. Fauna de Belo Horizonte e Jaboticatubas, Estado de Minas Gorais. Mem. Inst. Butantan 24: 45-62, 1952.

Recebido para publicaçăo em 15/2/1984. 